\title{
Sustainability of high-country pastures under contrasting development inputs
}

\author{
D. SCOTT \\ AgResearch, PO Box 60 Lincoln New Zealand \\ scottd_hc@xtra.co.nz
}

\begin{abstract}
The paper précis the key published results from two 26year grazing trials, involving an initial 25 species mix under 35 different $\mathrm{S}$ and $\mathrm{P}$ fertiliser rates, three sheep stocking rates and two stocking combinations. Species separation and transition from legume to grass dominance depended on fertiliser rate. Alsike and white clover dominated early stages at moderate fertiliser rates. The horticultural lupin was a highly successful pasture legume at low fertiliser inputs, and there was low success of introduced species without fertiliser. Caucasian clover established slowly but became the dominant legume in the second decade at higher fertiliser rates. Chewing fescue was the second most successful grass across the whole fertility gradient, cocksfoot reached maximum prominence towards the end of first decade, and tall oat grass increased over time. Grazing management effects on pasture species selection was small relative to fertiliser effects. Grazing capacity, as measured by sheep grazing days, was mainly determined by sulphur fertiliser rates. Nutrient budgets showed the large below-ground components which increased with fertiliser rates, stocking rate, and mob versus set stocking.
\end{abstract}

Keywords: high country, species suitability, Caucasian clover, lupin, grazing capacity, nutrient balance, fertiliser efficiency, sulphur

\section{Introduction}

In seeking to understand the relationship between the agriculture options and potentials of the South Island high-country compared to that of the native tussock vegetation, or of pasture agriculture elsewhere, we developed the concept of environmental gradients and species niches (Scott et al. 1995). That concept saw pasture production anywhere as being primarily determined by a site's position within four environmental gradients - (1) moisture as related to rainfall, drainage and topography; (2) temperature as related to latitude, altitude, aspect and slope; (3) soil fertility either natural or applied; and (4) the interaction of grazing animals with plant growing points. Within those gradients, each pasture species was seen as having a niche where it was best suited for the particular combination of environmental and management conditions.

This was the basis of the two trials established in 1982 in which a common seed mixture containing a multitude of contending species was sown onto a single high- country site and then fenced off into many different fertiliser, sheep stocking rate and stocking method combinations. What was of interest was the degree to which species might sort themselves out in the different conditions and contribute to the production. The trials also served a practical purpose of identifying the best pasture species for the different combinations of fertiliser and management inputs. By following them for the 26 years to date, information has also been obtained on production, sustainability of pasture species, sheep production and changes in soil characteristics over that time scale.

The present paper summarises the more important results extensively reported elsewhere (Scott 1999, 2000a,b,c,d,e,f, 2001, 2002, 2007; Scott \& Penell, 2006).

\section{Methods}

Three trials were involved in the study. They were adjacent to each other at the AgResearch Mt John trial site, Lake Tekapo and were established by partial over-drilling of mouse-ear hawkweed (Hieracium pilosella) infested fescue tussock (Festuca novae-zelandiae) grasslands.

In one trial the main treatment blocks were two spatial replications of five fertiliser/growth regimes of nominally $0,50,100,250$ or $500 \mathrm{~kg}$ super phosphate/ha/yr (hereafter referred to as the Graze/fert trial). The superphosphate was sulphur fortified to $20-50 \% \mathrm{~S}$ at the 50 and $100 \mathrm{~kg} /$ ha/yr super phosphate rate, with double the fertiliser rate in the initial year. The $500 \mathrm{~kg} / \mathrm{ha} / \mathrm{yr}$ blocks also received spray irrigation from late spring to autumn. Within the main treatment blocks were further grazing treatments of three relative stocking-rates ('under-utilized , 'best guess' and "over-grazed" with sheep numbers for the three in the ratio of 2:3:4), by two grazing-methods (high sheep numbers for 5-7 days, i.e. mob-stocking; or few sheep for longer periods, i.e. sustained or set-stocking). Each fenced treatment combination was $8 \times 50 \mathrm{~m}$.

The second trial was a response surface design of 27 combinations of S fertiliser (as elemental sulphur) and $\mathrm{P}$ fertiliser (as triple phosphate with $20 \% \mathrm{P}$ ) of nominally $0,5,10,20,50$ or $100 \mathrm{~kg}$ element $/ \mathrm{ha} / \mathrm{yr}$ (hereafter referred to as the PxS trial). Four of the combinations were repeated with the addition of potassium and micronutrients. Each fenced treatment combination was $12.5 \times 12.5 \mathrm{~m}$. The fertiliser rates were doubled in the initial sowing year with half the sulphur applied as gypsum in that year. 
The fertiliser was applied annually in early spring. Annual variations in the proximate analysis of $\mathrm{P}$ and $\mathrm{S}$ contents of the superphosphate were taken into account.

The trials were sown with a common mixture of 25 different legumes and grasses, using a rotary hoe drill that cultivated and sowed into about a third of the area it passed over (Scott \& Covacevich 1987; Scott 1999). The plots were given nearly two growing seasons to establish before commencement of the grazing treatments in the second autumn. Fertiliser application ceased after 20 years.

From the third year on, plots were grazed from November to May as required. For the PxS trial, that involved common mob-stocking on two or three occasions each year and for 4-8 days each time. For the Graze/fert trial, the number of grazings varied with fertiliser rate. The plots were grazed in groups of three for each of the different stocking-rate and grazing-method combinations. The plots were grazed as judged from the moderate stocking rate plot, with the other two plots receiving their differential stocking rate for the same period. For the moderate stocking rate treatments (and all the PxS plots), this was when feed on offer was 1-2 $\mathrm{t} \mathrm{DM} / \mathrm{ha}$, and ceased when plots were grazed to a residual 1-2 cm height. Annual grazing-days/ha, and cumulative grazing-days/ha for up to 5 years previously, was determined for each plot.

Soils were sampled and analysed to $400 \mathrm{~mm}$ depth during the 10th-15th year period and nutrient budgets determined.

A third trial, commenced a number of years following the earlier two, investigated three sowing configurations of a similar multi-species mixture: from a single composite mix, or species and cultivars separated in 16 different mixtures, or each species or cultivar in a singlecoulter row and cross-drilled with others, with all three treatments subsequently under a similar range of treatments and management regimes as the earlier trials.

\section{Results \\ Pasture species and fertiliser}

There was early sorting out of pasture species according to the fertiliser rate used and gradual change from legume to grass dominance (Table 1).

Generally, alsike (Trifolium hybridum) and white clover (T. repens) were initially dominant in the high fertiliser dryland and the single irrigated treatment for the first period. Alsike clover generally dominated several of the moderate fertiliser rate and grazing treatments in the early periods, as did perennial lupin (Lupinus polyphyllus). Lupin dominated most of the lower fertiliser rate treatments, becoming increasingly dominant, and at the lowest fertiliser rates in several of the treatments has maintained that dominance to date. Caucasian $\operatorname{clover}(T$. ambiguum) was slow to establish, but increased to become the dominant legume and species at the higher fertiliser rates in the second decade.

Cocksfoot (Dactylis glomerata) reached its maximum dominance towards the end of the first decade. Chewings fescue (Festuca rubra var. commutata) was the dominant grass at the highest fertiliser plus irrigation treatment and the second most common grass across all fertiliser rates. Tall oat grass (Arrhenatherum elatius), while initially rare, increased from self-seeding to become the dominant grass in the moderate to high fertiliser dryland treatments by the end of the second decade. Perennial ryegrass (Lolium perenne), though sown along with other species, was only ever a rare species. Tall fescue (Festuca arundinacea) and timothy (Phleum pratense) remained a component of the high fertility plus irrigation treatment.

The transition from legume dominance to grass dominance depended on fertiliser rate, with many of the lower fertiliser rate treatments remaining legume dominant by lupin to date. At the highest fertiliser rate, the initial legume dominant phase was for 2-4 years and at moderate fertiliser rates was 5-10 years, with, in many of those, a return to legume dominance in later periods by Caucasian clover as that species increased vegetatively. The key implication is that pasture species need to be matched with the intended fertiliser rate.

As the treatment combinations of stocking-rate and stocking-method in the Graze/fert trial imply, about two thirds of the treatments were deliberately 'mismanaged' by good pasture management standards, to determine what pasture species would tolerate such conditions. The effects of the grazing management treatments on pasture species success and pasture composition were relatively small relative to the large effect of fertiliser rates (Table 1). During the first decade, while it was possible to see differences between the pastures during the late-spring to autumn grazing period, by the time pastures had had a common rest and regrowth period over the subsequent winter and spring, the differences related to grazing management treatments were small. It was only during the second and subsequent decade that grazing management treatments had imposed permanent changes on pasture species composition in terms of species extinctions or increases (Table 1).

\section{Sheep grazing capacity}

Sheep grazing capacity of each plot was determined as the yearly total over 24 years using the product of the number of sheep and days grazed. An approximate conversion to annual SUs was by a further division of 2.5 (Table 2).

This grazing capacity ranged from ca. $0.8 \mathrm{SU} / \mathrm{ha}$ under nil fertiliser to $2.7-3.1 \mathrm{SU} / \mathrm{ha}$ for the $50-250 \mathrm{~kg} / \mathrm{ha} / \mathrm{yr}$ dryland super-phosphate rates (with the higher value for 
Table 1 Change in species dominance over six periods in 25 years related to fertiliser levels (superphosphate in $\mathrm{kg} / \mathrm{ha} / \mathrm{yr}: 1=\mathrm{nil}, 2=50,3=100,4=250$, and $5=500$ +irrigation) and grazing management $(\mathrm{H}=\mathrm{high}$ stocking rate, $\mathrm{M}=$ moderate, $\mathrm{L}=$ low, and $\mathrm{s}=$ set-stocking and $\mathrm{m}=$ mob-stocking).

$\mathrm{a}=$ alsike clover, $\mathrm{C}=$ chewings fescue, $\mathrm{D}=$ cocksfoot, $\mathrm{H}=$ Hieracium, $\mathrm{K}=$ Caucasian clover, $\mathrm{L}=\mathrm{lupin}$, $\mathrm{O}=$ tall oat grass, $\mathrm{W}=$ white clover, and $\mathrm{Z}=$ fescue tussock.

\begin{tabular}{|c|c|c|c|c|c|c|}
\hline \multirow[t]{2}{*}{ Grazing } & Year 2-4 & Year 5-8 & Year 9-12 & Year 13-16 & Year 17-20 & Year 21-24 \\
\hline & 12345 & 12345 & 12345 & 12345 & 12345 & 12345 \\
\hline $\mathrm{Hs}$ & $\mathbf{L}$ a $a \mathbf{L}$ a & $\mathrm{H}$ a a $\mathrm{H} \mathrm{W}$ & $\mathrm{H}$ L K K C & $\mathrm{HKKKC}$ & $\mathrm{HKKKC}$ & $\mathrm{H} \mathrm{K} \mathrm{K} \mathrm{K} \mathrm{C}$ \\
\hline Ms & $\mathbf{L} \mathbf{L}$ a $\mathbf{L}$ a & $\mathrm{H} \mathbf{L} \mathbf{L}$ a $\mathrm{W}$ & H L L K C & H L L K C & $\mathrm{H} \mathbf{L} \mathbf{L} \mathrm{K} \mathrm{C}$ & $\mathrm{H} \mathrm{L} \mathrm{L} \mathrm{K} \mathrm{C}$ \\
\hline $\mathrm{Hm}$ & $\mathbf{L} \mathbf{L} \mathbf{L} \mathbf{L} \mathbf{W}$ & $\mathbf{L} \mathbf{L} \mathbf{L} \mathbf{L} \mathbf{D}$ & $\mathrm{H} \mathbf{L} \mathbf{L} \mathbf{L} \mathbf{K}$ & L K K L K & $\mathrm{LKKKK}$ & $\mathrm{L} K \mathrm{~K} \mathrm{KK} \mathrm{K}$ \\
\hline $\mathrm{Mm}$ & $\mathbf{L} \mathbf{L} \mathbf{L} \mathbf{L}$ a & $H \mathbf{L} \mathbf{L} \mathbf{L} \mathrm{D}$ & $H \mathbf{L} \mathbf{L} \mathbf{L} \mathbf{D}$ & $\mathrm{H} \mathbf{L} \mathbf{L} \mathbf{L} \mathrm{C}$ & $\mathrm{HKKKK}$ & $\mathrm{H} O \mathrm{O} \mathrm{KC}$ \\
\hline Ls & $\mathbf{L} \mathbf{L} \mathbf{L} \mathbf{L} \mathbf{a}$ & $H \mathbf{L} \mathbf{L} \mathbf{L} \mathrm{D}$ & $\mathrm{H} \mathbf{L} \mathbf{L} \mathbf{L} \mathrm{C}$ & $\mathrm{H} \mathbf{L} \mathbf{L} \mathbf{L} \mathbf{C}$ & $\mathrm{ZKKKK}$ & $\mathrm{Z} O \mathrm{O} \quad \mathrm{K} \mathrm{C}$ \\
\hline Lm & $\mathbf{L} \mathbf{L}$ a $\mathbf{L}$ a & $\mathrm{H} \mathbf{L} \mathbf{L} \mathbf{L} \mathbf{L}$ & $\mathrm{H} \mathbf{L} \mathbf{L} \mathbf{L} \mathbf{L}$ & $Z \mathbf{L} \mathbf{L} \mathbf{L} \mathbf{C}$ & $\mathrm{Z} O 0 \quad 0 \quad \mathrm{~K}$ & $\begin{array}{lllll}Z & 0 & 0 & 0 & 0\end{array}$ \\
\hline
\end{tabular}

Table 2 Sheep grazing capacities (24 year mean of six grazing intensities and methods) and nutrient pools ( $\mathrm{t}$ / ha) under contrasting fertiliser levels in the Graze/fert trial.

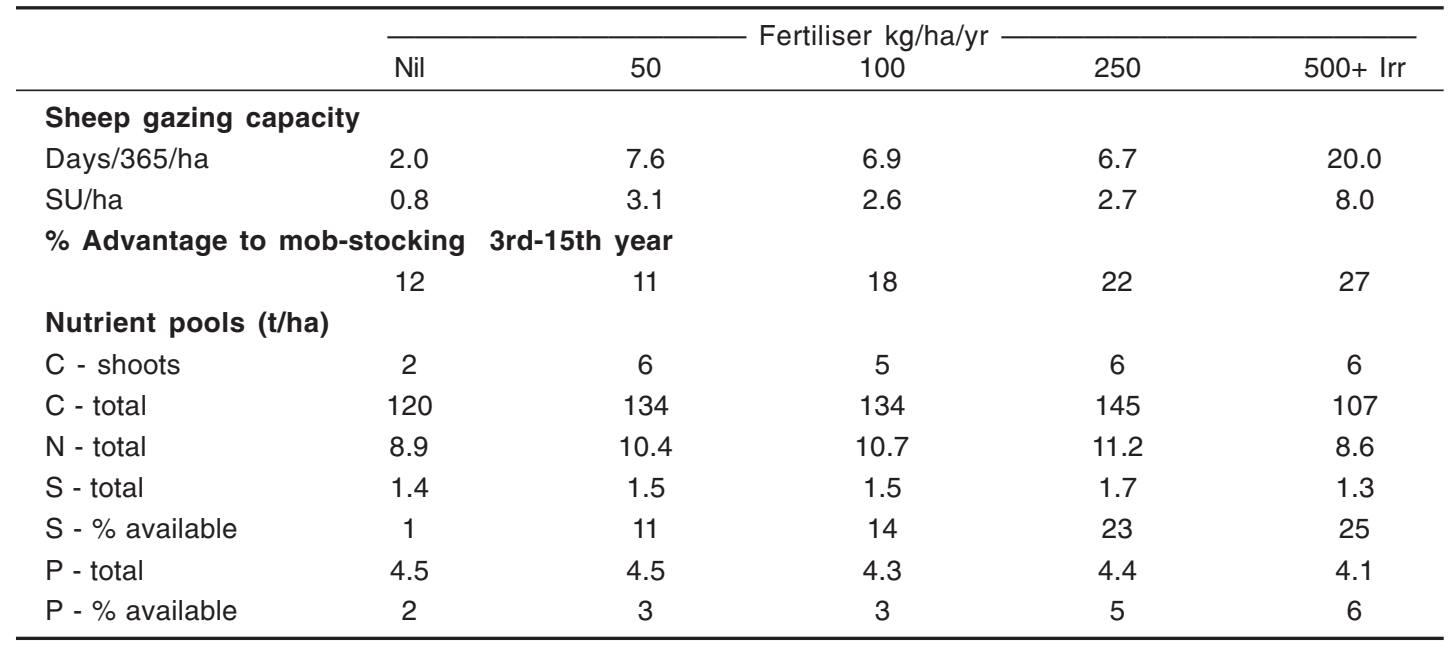

the perennial lupin-dominated lower fertiliser rate treatments), to $8.0 \mathrm{SU} / \mathrm{ha}$ for the single high fertiliser and irrigated treatment (Table 2). For the initial 15 years there was an increase in carrying capacity from mob versus set stocking with that advantage increasing for the higher fertiliser rates.

Grazing capacity fluctuated with years according to climate-determined pasture growth. The trend was for an initial rise in 1984-86, a stable period between 198689 , a decrease between 1989-94, a return to stable levels in 1993-95, a subsequent small increase in 1995-97, then remaining relatively constant but a decline after fertilisation ceased in 2002 .

\section{Fertiliser $-S$ versus $P$}

In the PxS trial there were 31 different combinations of $\mathrm{S}$ and $\mathrm{P}$ fertiliser rates under 'best guess' pasture management. The trial indicated that the different pasture species were tending to sort themselves out according to the $\mathrm{P}$ fertiliser rate and that the few measurements of herbage yields showed a response to both $\mathrm{S}$ and $\mathrm{P}$ fertiliser rate. However, grazing capacity, as determined by sheep grazing days achieved, was determined solely by $\mathrm{S}$ fertiliser rates. While this is partly explained with the high S content of wool, it does raise the question: does our plant based concept of soil fertility correctly determine potential animal production?

\section{Fertiliser efficiency}

Fertiliser efficiency can be defined as the grazing capacity gained versus fertiliser dollars spent. Using 15 years of grazing records from the two trials with their 35 different $\mathrm{S}$ and $\mathrm{P}$ fertiliser combinations, the most profitable fertiliser combination for long-term sustainable production was determined after considering fertiliser composition, ex-works, transport, and spreading costs, increase in sheep carrying capacities, and discount rate. For the soils of the trial area with a high natural P level, the optimum returns were determined solely by the elemental-S fertiliser rates. The estimated greatest net return from annual application rates was at $53 \mathrm{~kg} \mathrm{~S} / \mathrm{ha} /$ $\mathrm{yr}$, or between 24 and $39 \mathrm{~kg} \mathrm{~S} / \mathrm{ha} / \mathrm{yr}$ if the ratio of return 
versus input was considered. Using the responses in carrying capacities and elemental-S oxidation rate, it was estimated that the best long-term sustainable fertiliser strategy was for 5 -yearly application of $250 \mathrm{~kg} / \mathrm{ha}$ of 2.2-mm coarse-particle elemental-S.

The estimates of fertiliser efficiency are in terms of fertiliser and sheep production costs and returns. However, these needed to be matched with the pastures species most suitable to those fertiliser levels. In these trials it was the perennial lupin.

\section{Nutrient balance}

Nutrient contents of shoots, litter, roots and soils were measured to $400 \mathrm{~mm}$ depth. Most of the nutrient pools were below ground and only a small proportion was directly available to plants. The total carbon pool exceeded $100 \mathrm{t} / \mathrm{ha}$ in all treatments and in dryland treatments increased with fertiliser rate (Table 2). The increase in the $\mathrm{N}$ pool was related to fertiliser rate rather than the legume mass or species involved. The $\mathrm{N}$ fixation rate was ca. $200 \mathrm{~kg} / \mathrm{ha} / \mathrm{yr}$. The present work, together with that of other investigators, indicates that $\mathrm{S}$ supplementation may be more important than $\mathrm{P}$ in drier regions, but there is still insufficient understanding of the processes involved and monitoring methods. The potential plant-available S pool was estimated to be ca. $1.5 \mathrm{t} / \mathrm{ha}$, with a considerable component of un-weathered residual elemental S. The total $\mathrm{P}$ was ca. $4.5 \mathrm{t} / \mathrm{ha}$ of which $2-6 \%$ was in a plant available form.

The exceptions to the general increase in nutrient pools with greater fertiliser inputs were the P pool and the single irrigated treatment. The apparent decrease in the $P$ pool with increasing fertiliser rates related to soil expansion from the enhanced plant growth which resulted in lesser sampling of the sub-soil $\mathrm{P}$ accumulation layer when a common standard sampling depth was used. The soil had expanded between $0-40 \mathrm{~mm}$ in $400 \mathrm{~mm}$ depth zone during a decade depending on fertiliser rate. The lack of apparent gain in soil nutrients under irrigation was interpreted as the effect of additional moisture giving greater rates of organic matter mineralisation and nutrient turn-over.

Stock off-take of nutrients was small as estimated from grazing days, a few measurements of annual weight gains, and assumed sheep mineral composition data. In general the animal's 10-year off-take was less than half of that in a 1-year spring herbage mass, and fertiliser inputs exceeded stock off-take by a factor of 30-90 fold for S and 4-20 fold for P.

In relation to grazing management, results indicated that total $\mathrm{C}$ and $\mathrm{N}$ pools were greater under mob than set stocking, and that a greater proportion of total N, S and $\mathrm{P}$ pools were within the organic matter pools as stocking rate increased.

\section{Multi-species mixtures}

The pasture compositions from the three different sowing configurations in the third trial converged for each of the different fertiliser and grazing management treatments. Collectively the three trials show that multi-species mixtures can be used as a research technique to find which are the most suitable species or cultivars for a particular set of environmental and management conditions, even though subsequent sowing recommendations would be confined to the most suitable few.

\section{Discussion and Conclusions}

The paper can only give a précis of the methods and results from these and other trials more extensively reported elsewhere. Collectively they support the notion that each pasture species has a place where it is 'king' according to the particular combination of environmental conditions and stage of soil fertility development.

\section{Soil fertility}

The present results indicate that outputs are more determined by soil fertility conditions (either natural or applied) than by grazing management effects (though it is probably true that all species considered had passed the test of being able to survive under grazing before being considered for sowing). The present trial also suggest that the initial sowing of a multiple species mixture (as a research rather than a practical application technique), may be a convenient method of determining which small group of species are most suitable for each set of environments and proposed management conditions.

\section{Environment not species}

The second aspect of the present trials, as reflected in grazing capacity results, is that production is primarily determined by environment, which for a particular site is principally soil fertility, and not by pasture species per $s e$. This is illustrated by the lack of success of most sown 'high producing' species in the non-fertiliser treatments, and the general lack of success of perennial ryegrass in any of the treatments. If we wish to change the production levels then it is the environment (soil fertility) that has to be changed, not just the pasture species used.

\section{Get your species right}

This is a continuation of the notion that each species has a place, and is illustrated in the present trials by the separation of species among the different fertiliser levels from an original common mixture. That selection will be determined by the particular site being considered, the proposed fertiliser inputs, the proposed grazing managements to be applied, and the intended duration. 
Dollars gained for dollars spent

The choice of species may be determined by considerations other than production. The present work looked at fertiliser efficiency as dollars returned for dollar spent, with the most efficient being ca. $50 \mathrm{~kg} / \mathrm{ha} / \mathrm{yr}$ elemental S. The most suitable species at that level was perennial lupin. Thus an alternative wording was Match your species with the intended inputs and management.

My own view is that is that there may be an addendum - Get your species right before worrying too much about cultivars. This was investigated as part of the components of the species mixtures used. Cultivars are only small variants of the same general species characteristics - a browntop cultivar is not a ryegrass in disguise. The same approach of an initial screening through multi-mixtures is appropriate.

The trial results contribute to possible 'rules-of-thumb' for the likely development in the hill and high country, namely:
4-5 for $\mathrm{S}$ and $\mathrm{P}$ fertiliser
2-3 for irrigation water
$\pm 2-3$ for grazing management
2-3 for $\mathrm{N}$ fertiliser

The $\mathrm{S}$ and $\mathrm{P}$ fertiliser and water effects are initially separated, but fertilisation will generally always accompany irrigation, to give a 10 -fold increase with irrigation development. The grazing management effect includes the deliberate \pm to emphasis that while the fertiliser and irrigation responses will almost always be positive, the difference between good and bad pasture management can be large.

\section{ACKOWLEDGEMENTS}

A.W. Simpson, H. Hunter-Weston and Defence Dept for land and stock, Ravensdown for fertiliser, and L.A. Maunsell, J.S. Roberston and B.L. Sutherland for technical support.

\section{REFERENCES}

Scott, D. 1999. Sustainability of New Zealand highcountry pastures under contrasting development inputs. 1. Site, and shoot nutrients. New Zealand Journal of Agricultural Research 42: 365-383.

Scott, D. 2000a. Fertiliser and grazing rejuvenation of rejuvenation of fescue tussock. New Zealand Journal of Agricultural Research 43: 481-490.
Scott, D. 2000b. Sustainability of New Zealand highcountry pastures under contrasting development inputs. 2. Soil inorganic components. New Zealand Journal of Agricultural Research 43: 101-125.

Scott, D. 2000c. Sustainability of New Zealand highcountry pastures under contrasting development inputs. 3. Sheep carrying capacity. New Zealand Journal of Agricultural Research 43: 175-185.

Scott, D. 2000d. Sustainability of New Zealand highcountry pastures under contrasting development inputs. 4. Organic matter components. New Zealand Journal of Agricultural Research 43: 387-415.

Scott, D. 2000e. Sustainability of New Zealand highcountry pastures under contrasting development inputs. 5. Nutrient pools and balances. New Zealand Journal of Agricultural Research 43: 415-438.

Scott, D. 2000f. Sustainability of New Zealand highcountry pastures under contrasting development inputs. 6. Fertiliser efficiency. New Zealand Journal of Agricultural Research 43: 525-532.

Scott, D. 2001. Sustainability of New Zealand highcountry pastures under contrasting development inputs. 7. Environmental gradients, plant species selection, and diversity. New Zealand Journal of Agricultural Research 44: 59-90.

Scott, D. 2002. Sustainability of New Zealand highcountry pastures under contrasting development inputs. 8. Modelling sheep carrying capacity. New Zealand Journal of Agricultural Research 45: 151-163.

Scott, D. 2007. Sustainability of New Zealand highcountry pastures under contrasting development inputs. 9. Vegetation interactions. New Zealand Journal of Agricultural Research 50: 393-406.

Scott, D.; Covacevich, N. 1987. Effects of fertiliser and grazing in a pasture species mixture in high country. Proceedings of the New Zealand Grassland Association 48: 93-98.

Scott, D.; Maunsell, L.A.; Keoghan, J.M.; Allan, B.E.; Lowther, W.L.; Cosssens, G.G. 1995. A guide to pastures and pasture species for the New Zealand high country. Grassland Research and Practice Series No 4: 1-41.

Scott, D.; Pennell, C.G.L. 2006. Agronomic methods: Evaluation by multiple species pasture mixtures. New Zealand Journal of Agricultural Research 49:191200. 